\title{
Orthodontic 2D and 3D frontal sinus imaging records: an important role in human
}

\section{identification}

\author{
Arquivos de imagens ortodônticas 2D e 3D do seio frontal: um papel importante na identificação
}

humana

Archivos de imágenes de ortodoncia del seno frontal 2D y 3D: un papel importante en la

identificación humana

Received: 03/06/2021 | Reviewed: 03/12/2021 | Accept: 03/16/2021 | Published: 03/23/2021

\author{
Franciéllen de Barros \\ ORCID: https://orcid.org/0000-0001-5460-4334 \\ São Paulo State University, Brazil \\ E-mail: fran.dbrs@gmail.com \\ Mônica da Costa Serra \\ ORCID: https://orcid.org/0000-0001-8820-2982 \\ São Paulo State University, Brazil \\ E-mail: monica.serra@unesp.br \\ Barbara Kuhnen \\ ORCID: https://orcid.org/0000-0003-2586-4772 \\ São Paulo State University, Brazil \\ E-mail: kuhnenbarbara@gmail.com \\ Rienne Assis Matos \\ ORCID: https://orcid.org/0000-0002-8183-4001 \\ São Paulo State University, Brazil \\ E-mail: rienne@outlook.com.br \\ Clemente Maia da Silva Fernandes \\ ORCID: https://orcid.org/0000-0002-5401-6265 \\ São Paulo State University, Brazil \\ E-mail: c.face@ terra.com.br
}

\begin{abstract}
Two-dimensional imaging records, as conventional radiographies, are part of the orthodontic clinic routine; frontal sinus images are often present in these exams. The characteristics of the frontal sinus are information of great relevance for the Forensic Sciences, as their images may be used for human identification purposes. With the advent of new threedimensional technologies and computerized image examinations such as Computed Tomography (CT), threedimensional analysis of the frontal sinuses has become possible. This article evaluates the possibilities of human identification using frontal sinuses 2D and 3D images and the role of orthodontists in this context. Pubmed, SciELO, LILACS and Web of Science were used as databases. As inclusion criteria, were selected texts concerning the studied issue. Although the analysis of frontal sinuses is traditionally carried out using two-dimensional images, there is a growing trend of studies employing CT scans. Cone-Beam Computed Tomography (CBCT) is an important diagnosis tool, more frequently used in orthodontics, which allows a three-dimensional approach and great precision in measurements. Together with two-dimensional analysis of frontal sinuses, 3D images are of great value for human identification. Although three-dimensional analysis is not yet a routine, its Forensic use is undoubtedly an excellent tool provided by new technologies. It is important that the orthodontist knows this possibility by properly keeping the patients' imaging exams.
\end{abstract}

Keywords: Forensic dentistry; Orthodontics; Three-dimensional imaging; Cone-beam computed tomography; Frontal sinus; Forensic sciences.

\section{Resumo}

Registros de imagens bidimensionais, como as radiografias convencionais, fazem parte da rotina da clínica ortodôntica; imagens do seio frontal estão frequentemente presentes nesses exames. As características do seio frontal são informações de grande relevância para as Ciências Forenses, pois suas imagens podem ser utilizadas para fins de identificação humana. Com o advento de novas tecnologias tridimensionais e exames de imagem computadorizados, como a tomografia computadorizada (TC), a análise tridimensional dos seios frontais tornou-se possível. Este artigo avalia as possibilidades de identificação humana por meio de imagens $2 \mathrm{D}$ e $3 \mathrm{D}$ dos seios frontais e o papel do ortodontista nesse contexto. Foram utilizadas como bases de dados: Pubmed, SciELO, LILACS e Web of Science. Como critérios de inclusão foram selecionados textos que retratassem a temática. Embora a análise dos seios frontais 
seja tradicionalmente realizada por meio de imagens bidimensionais, há uma tendência crescente de estudos com tomografia computadorizada. A Tomografia Computadorizada de Feixe Cônico (TCFC) é uma importante ferramenta diagnóstica, mais utilizada na Ortodontia, que permite abordagem tridimensional e grande precisão nas medidas. Juntamente com a análise bidimensional dos seios frontais, as imagens 3D são de grande valor para a identificação humana. Embora a análise tridimensional ainda não seja uma rotina, seu uso Forense é, sem dúvida, excelente ferramenta proporcionada pelas novas tecnologias. É importante que o ortodontista conheça essa possibilidade guardando de maneira adequada os exames de imagem dos pacientes.

Palavras-chave: Odontologia Legal; Ortodontia; Imagem Tridimensional; Tomografia computadorizada de feixe cônico; Seio frontal; Ciências forenses.

\section{Resumen}

Los registros de imágenes bidimensionales, como las radiografías convencionales, son parte de la rutina de la clínica de ortodoncia; las imágenes del seno frontal están presentes con frecuencia en estos exámenes. Las características del seno frontal son información de gran relevancia para las Ciencias Forenses, ya que sus imágenes pueden ser utilizadas con fines de identificación humana. Con el advenimiento de las nuevas tecnologías tridimensionales y los exámenes de imágenes computarizados, como la tomografía computarizada (TC), se ha hecho posible el análisis tridimensional de los senos frontales. Este artículo evalua las posibilidades de identificación humana a través de imágenes 2D y 3D de los senos frontales y el papel del ortodoncista en este contexto. Se utilizaron como bases de datos Pubmed, SciELO, LILACS y Web of Science. Como criterio de inclusión, se seleccionaron textos que retrataran el tema. Aunque el análisis de los senos frontales se ha realizado tradicionalmente mediante imágenes bidimensionales, existe una tendencia creciente en los estudios con tomografía computarizada. La tomografía computarizada de haz cónico (CBCT) es una importante herramienta de diagnóstico, más utilizada en ortodoncia, que permite un abordaje tridimensional y una gran precisión en las mediciones. Junto con el análisis bidimensional de los senos frontales, las imágenes en 3D son de gran valor para la identificación humana. Aunque el análisis tridimensional aún no es una rutina, su uso forense es sin duda una excelente herramienta proporcionada por las nuevas tecnologías. Es importante que el ortodoncista conozca esta posibilidad conservando adecuadamente los exámenes por imágenes del paciente.

Palabras clave: Odontología forense; Ortodoncia; Imagen tridimensional; Tomografía computarizada de haz cónico; Seno frontal; Ciencias forenses.

\section{Introduction}

Frontal sinuses are bilateral structures and, like fingerprints, they are unique in each individual. They are commonly observed in imaging exams asked by orthodontits, as radiographies and tomographies. So they are part of patients' dental records. And, as frontal sinuses present a different morphology for each person, they can be employed for human identification.

The identification process presents itself in a complex, systematic and organized way; its main objective is to verify the identity (a set of physical, functional or psychological, normal or pathological characteristics, which qualifies the individual as identical only to himself) of a person (Xavier et al., 2015; Nikam et al., 2015). Identification is a challenging task for humanity, although it presents great significance, because in addition to addressing humanitarian issues, it has direct implications in civil and criminal procedures (Dostalova et al., 2012).

There are several identification methods; the analysis of fingerprints is the most used when the tissue is viable for handling. DNA analysis is also employed, but this technique that costs a lot time, appropriate laboratory and it cannot be performed when the material is very degraded. Forensic Dentistry, the use of dental records to identify a person is a reliable, practical, fast and cheap identification method (Serra, Herrera \& Fernandes, 2012; Serra et al., 2014; Xavier et al., 2015). In this context, image exams, as radiographies and computed tomographies (CTs), can be a worth source of information, for human identification (Gioster-Ramos et al., 2021). Therefore, Silva et al. (Silva et al., 2021) highlighted the possibility of achieving positive human identification with precision, only with the contribution of a single tooth. Palatal rugoscopy is also an important technique for human identification, employed by Forensic Dentistry (Santos, Fernandes \& Serra, 2011; Manganotti et al., 2021).

Putrefied, skeletonized or charred bodies, especially in mass accidents, usually need identification, requiring the use of anthropological methods (Singh et al., 2013). The skull, pelvis and femur are the bones widely used in the sex estimation phase; however, in cases of trauma and accidents, hardly all these bone structures are found. The frontal sinus cavities, due to their resistance to damage, are very useful, as they are structures that are often protected, due to their resilience (Cox et al., 2009). 
There are no two individuals with identical frontal sinuses. In this way, it becomes a reliable comparative method of forensic interest for human identification (Caputo et al., 2011; Gadekar et al. 2019; Gioster-Ramos et al., 2021).

The evaluation of the frontal sinuses, even in monozygotic and dizygotic twins, shows that they have unique patterns, as well as being stable throughout life in all individuals. Thus, the reliability of comparing images, whether radiographic or from Computed Tomography (CT), ante and post-mortem of the frontal sinus for identification is valid (Trevelin \& Lopez, 2012). This analysis is possible because it is a structure commonly exposed in medical and dental investigations. Thus, frontal sinus patterns have the potential to be used for personal identification, age estimation, and sexual dimorphism (Cox et al., 2009).

This work evaluates the possibilities of human identification using frontal sinuses $2 \mathrm{D}$ and $3 \mathrm{D}$ images and the role of orthodontists in this context.

\section{Methodology}

This article was based on a descriptive literature review with a qualitative approach (Pereira et al., 2018), constituting a broad study, allowing the inclusion of experimental and non-experimental research, of theoretical and empirical literature, in order to deepen the knowledge on the studied subject. A comprehensive search was carried out in the primary databases: PubMed, SciELO, LILACS and Web of Science. The descriptors used were "forensic dentistry", "frontal sinus", "orthodontics", "human identification", "cone beam computed tomography" and "three-dimensional images".

Initially, the search for descriptors was carried out individually and later crossings were made between them. For sample selection, articles, dissertations and theses that were available in full, published in Portuguese or English, in any period of time concerning the studied issue were included. The exclusion criteria were texts published in languages other than English and Portuguese and those that were not related to the studied topic. The search was classified and evaluated, ending with the interpretation of results and summary of knowledge.

This paper also has a theoretical and reflexive approach, carried out from the reading of Brazilian legislation regarding dental records and of imaging exams used by orthodontists.

\section{Frontal Sinuses}

The frontal sinuses are contained within the frontal bone, in the upper part of the superciliary arch, and consist of two air-filled cavities originating at the root of the nose and from the upper expansion in the peri-glabellar region. They are usually present in pairs - each one develops separately, there is a septum, that is most cases is deviated from the midline (Cossellu et al., 2015; Oliveira et al., 2020). Occasionally, one or both sinus may be absent. The prominence of the superciliary arches does not indicate the absence, presence or size of the frontal sinus. In some cases, the sinus may be overlapped in front of the other (Pondé et al., 2008).

These structures develop as diverticula from the lateral nasal wall, around the fourth fetal month after the development of the frontal recess (Michel et al., 2015), being visible until the end of the first year, and cannot be detected in a simple radiological film until 3 years old. They complete their development approximately at age 20, and remain stable throughout life (Michel et al., 2015). Tatlisumak et al. evaluated 300 individuals using CT images to measure height, width and length of each frontal sinus and also the total width of each individual's sinuses. The authors verified that, in general, the highest values were observed in the age group of 31-40 years., with a tendency to decrease with time (Tatlisumak et al., 2008).

Among the rare changes that can affect this structure throughout life, causes such as tumors, fractures or infections can be mentioned (Goyal, etl a., 2013). However, the ability to identify remains using visual inspection of the frontal sinus is reported to be unaffected by the elapsed ante-mortem and post-mortem time (Cox et al., 2009). Its patterns are considered unique and its conformation proves to be highly individualized, in addition to showing itself as a powerful marker of personal identification 
(Michel et al., 2015). The uniqueness of its morphology is supported by the discovery of the differentiation of these structures even in monozygotic twins (Cox et al., 2009; Besana \& Rogers, 2010; Trevelin \& Lopez, 2012).

When dealing with the forensic situation, frontal sinus resilience becomes useful. Such a structure can be readily recovered intact with all its internal configuration preserved due to its intrinsic bone part and arched nature, which protects it from damage and decomposition, being convenient in cases of victims who were carbonized (Besana \& Rogers, 2010; Silva et al., 2019).

\section{Human Identification by Frontal Sinuses Analyses}

Identification methods are comparative methods, i.e., it is necessary a first register of a known person to compare to a second register (of the deceased individual) of the analysed feature (Fernandes et al., 2013; Kuhnen et al., 2021; Barros et al., 2021). In forensic anthropology, the use of radiographic images of the frontal sinuses for human identification has been increasingly applied. The widespread use of conventional radiographs can be attributed to the fact that They are an inexpensive acquisition method, commonly available and practical for evaluating bone structures. They have the advantage of being well publicized and accessible, commonly used in cases of comparative identification processes (Goyal, etl a., 2013; Soares et al., 2016).

Radiological images of frontal sinuses are considered complementary exams in identification processes; a morphometric comparison of the frontal sinuses is performed, comparing shapes, size, symmetry, external borders and the presence of septa and cells in the images available by using radiographs and or CT scans before and post-mortem (Quatrehomme et al., 1996; Caputo et al., 2011; Franco et al., 2020; Gioster-Ramos et al., 2021).

The comparison of antemortem and postmortem radiographs of the frontal sinus can be done in an overlapping way or through coding systems. However, the overlapping of images has been questioned, since it requires images obtained with the same parameters at both times, despite being a technique accepted as reliable (Cossellu et al., 2015).

The use of dental radiographs, such as intraoral radiographs, panoramic radiographs and CT, has become quite common and routine in forensic cases, to obtain human identification (Gruber \& Kameyama, 2001; Wood, 2006). CT is the recommended exam to perform the study of paranasal sinus morphology, due to its advantages, as: higher resolution, without overlapping elements, provision of three-dimensional scanning of these components, in addition to allowing precise and exact measurements (Tucunduva \& Freitas, 2008; Uthman et al., 2010).

According to several authors, CT is the imaging technique used in the analysis of frontal sinuses (Tatlisumak et al. 2007; Tatlisumak et al., 2008; Tucunduva \& Freitas, 2008; Uthman et al., 2010). Although the two types of CT (traditional and cone beam computed tomography -CBCT), allow images to be obtained in sections of the dentomaxillofacial region, the use of CBCT has created new opportunities for obtaining images. When compared to multislice acquisition, CBCT presents lower doses of radiation, low cost, high resolution and short exam duration, in addition to allowing the visualization of axial, coronal, sagittal and oblique images, as well as three-dimensional reconstruction (Garib et al., 2007; Buscatti, 2009). Thus, the use of images produced from 3D CBCT has become popular in the different specialties of Dentistry (Buscatti, 2009).

The posteroanterior radiographs (AP) of the skull are very useful in the clinical course, identifying trauma or pathologies in the frontal sinuses. However, such images can also allow the visualization of the morphology of these structures, helping in cases of human identification (Silva et al., 2008).

As the frontal sinus presents differences in shape, area and symmetry and may be absent in only $4 \%$ of the population, this becomes an important parameter both for the classification of sexual dimorphism and human identification. In view of this, it is extremely important that the images obtained by PA skull radiographs are made using the method employed correctly, and within the appropriate parameters of elaboration (Camargo, 2000; Riepert et al., 2001; Wood, 2006). 
Hashim et al. (Hashim et al., 2015) when analyzing ante-mortem and post-mortem radiographs of two real cases and 12 simulated ones by overlap, found that the overlap of two frontal sinus radiographic patterns derived from the same skull only leads to a perfect overlap when orientation of the skull obtained in the first recording (simulated ante-mortem) is unchanged for the second (simulated post-mortem recording). Two problems were raised: 1. two 2D images are not superimposed even if they are derived from the same three-dimensional source; 2. the overlapping of two images in transparency would create a mixed third, leading to an illusion of compatibility.

Silva et al. (Silva et al., 2009) employed, on an identification case, the image comparison and direct measurement methods on posteroanterior (PA) radiographs, according to the parameters recommended by Ribeiro (Ribeiro, 2000). This method consists on measuring five reference lines in X-ray images, in which the first is drawn through the upper edge of the orbits and the others are drawn perpendicular to the first line, from the following points: the outermost point of the right frontal sinus; the outermost point of the left frontal sinus; the highest point of the right frontal sinus; and the highest point of the left frontal sinus. By associating the data obtained in the anthropological investigation and in the dental exam, it was possible to identify the individual.

Nikam et al. (Nikam et al., 2015) evaluated PA radiographs of 109 adult individuals (above 20 y.o.), excluding people who suffered trauma or had a pathology that affected the frontal sinus and those who did not have such structure. In their research, they demonstrated that both the maximum height and the maximum width of the frontal sinus were found as a unique characteristic for each of the subjects.

An effective comparison between ante and postmortem data in identification processes, depends on the quantity and quality of the information provided by dental records (Rothwell, 2001; Serra, Herrera \& Fernandes, 2012). It is important that dentists document well and keep their patients' clinical data (Serra et al., 2012; Serra et al., 2014). In particular orthodontists must, in addition to filling out clinical documents, keep all imaging exams of their patients, which may be essential in cases of human identification. As an example, frontal teleradiographies and CBCTs can be very helpful in these situations.

Figure 1 shows two frontal teleradiographies of the same individual, taken with an interval of 2 years. Figure 2 presents frontal teleradiographies of two different individuals, with and without the frontal sinuses highlighted.

Figure 1 - Frontal teleradiographies of the same individual, taken with an interval of 2 years. A. First image. B. Second image.
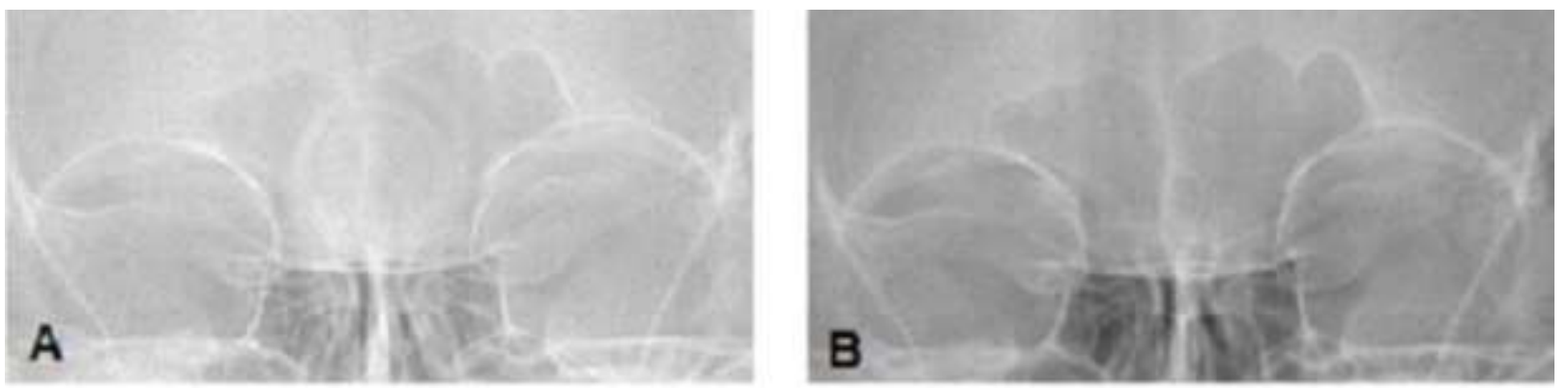

Source: Personal files of. Fernandes and Serra. 
Figure 2 - Frontal teleradiographies of two different individuals. A. Individual A. B. Individual B. C. Frontal sinus of individual A highlighted. D. Frontal sinus of individual B highlighted.
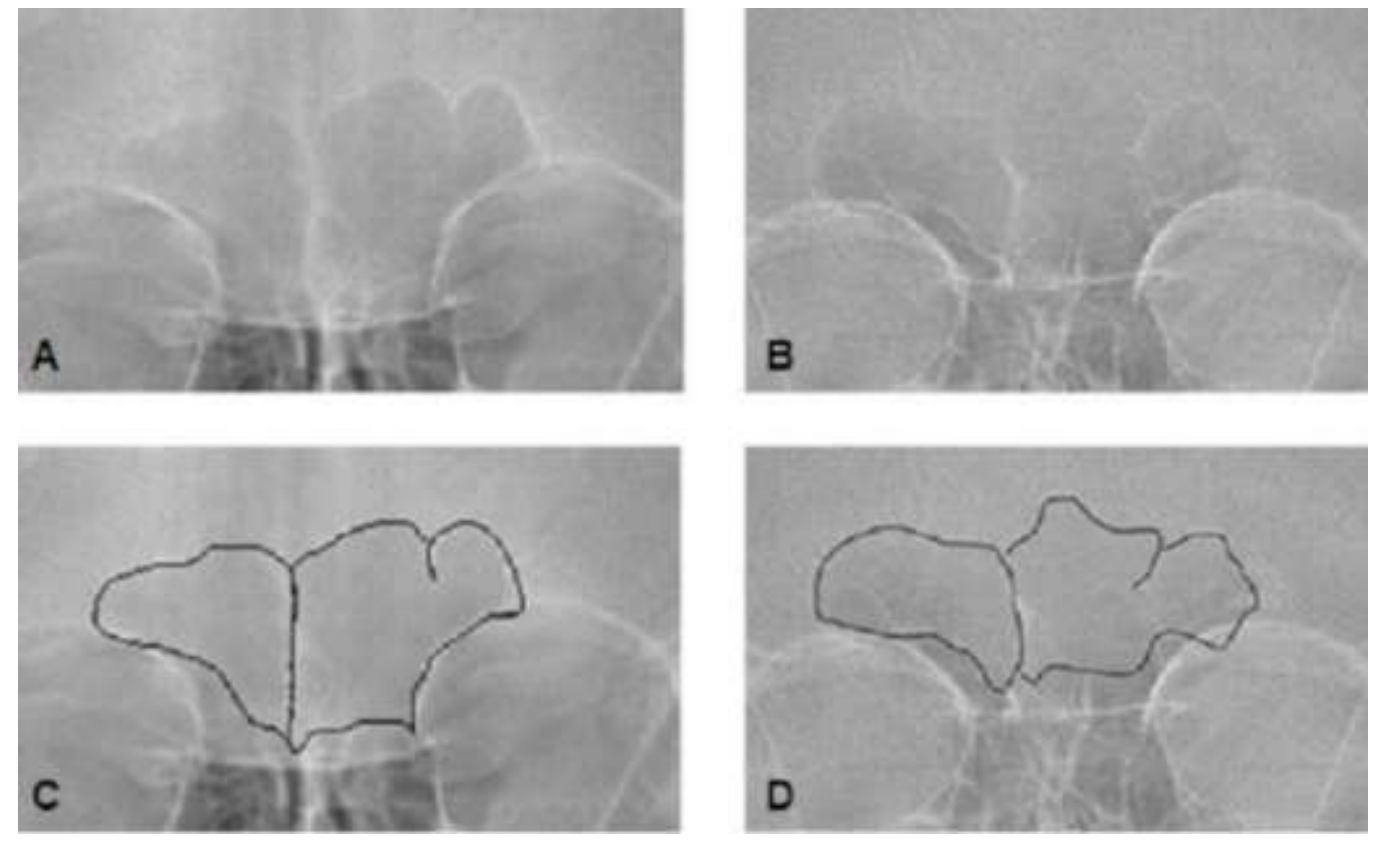

Source: Personal files of. Fernandes and Serra.

According to the Brazilian Dental Code of Ethics (Conselho Federal de Odontologia, 2012), it is duty of the dentists:

Art. 9, X: elaborate and keep updated the dental records, according to current legislation, including the digital records;

Article 17 states:

Art. 17. It is mandatory the elaboration and maintenance of legible and updated dental records and keeping them in proper physical or digital files.

Imaging exams and plaster models, among others, are complementary data from orthodontic treatment and are part of the dental records, clinically assisting the orthodontist in monitoring completed or ongoing treatments (Silva et al., 2011). In addition, these documents contribute to Forensic Dentistry due to issues related to the professional liability and in the processes of identifying cases of skeletonized, putrefied or charred bodies (Silva et al., 2005; Silva et al., 2009; Serra, Herrera \& Fernandes, 2012; Serra et al., 2014; Andrade et al., 2021).

\section{Discussion}

The employment of imaging exams in human identification is increasing day by day, although its use in Forensics depends on the availability of an antemortem exam. Radiographs are the most studied and publicized imaging exam; they have great applicability even nowadays, as they consist on a routine examination, guaranteeing the antemortem and postmortem data comparation (Goya et al., 2013; Cossellu et al., 2015; Soares et al., 2016).

Computer tomography provides a good opportunity to assess frontal sinuses with a three-dimensional approach and great precision in all measurements (Cappabianca et al., 2013). A significant advance in radiology is shown and is increasingly available and gradually replacing conventional radiographs, as they have several advantages over them, such as the nonoverlapping of structures beyond the chosen visual field, allowing the visualization of small differences in density. It allows not 
only the visualization of its internal structure, as well as its shape in relation to size, bilateral distribution and format (Carvalho et al., 2009; Uthman et al., 2010); internal points for evaluation can be easily shown by segmenting the image. Craniometric points can be located with precision and more accurate measurements than in conventional radiographs. Thus, volumes and areas can be determined (Carvalho et al., 2009).

Frontal sinus CT has replaced radiographs in routine medical practice. Studies have shown that the use of CT for morphometric investigations on the frontal sinus is easy and reliable for ante-mortem/post-mortem comparisons (Emirzeoglu et al., 2007; Tatlisumak et al., 2008). Three-dimensional reconstructions are an important part of virtual anthropology and have been dramatically increased for qualitative and quantitative morphological analysis (Jun et al., 2010). It is noteworthy that the three-dimensional images may represent the size and shape of the overlap with the antemortem radiographs (Pfaeffli et al., 2006).

Michel et al. (Michel et al., 2015) believe that three-dimensional reconstructions of the frontal sinus provide more reliable data (e.g.: volume) than two-dimensional measurements. The "size" of an anatomical structure such as the frontal sinus should, whenever possible, be assessed using three-dimensional measurements.

Cone Beam Computed Tomography presents technical features such as relatively low dosages, high quality and bone definition; its compact design have been attractive for intraoperative scanning of frontal sinuses. Its portability makes it ideal for use in the field (Pfaeffli et al., 2006).

Although the analysis of frontal sinuses is traditionally carried out using two-dimensional images, there is a growing trend of studies employing CT scans. Cone-Beam Computed Tomography is an important diagnosis tool, more frequently used in orthodontics, which allows a three-dimensional approach and great precision in measurements.

Improvements in three-dimensional radiographic techniques have generated a lot of data that can also be used for identification purposes. In comparison with traditional two-dimensional techniques, three-dimensional images yield more accurate and reliable information, such as volume assessment (Kim et al., 2013).

In certain cases, the analysis of frontal sinus measurements makes possible to determine sexual dimorphism, either by analyzing the measurements of its area or its volume, where the males present higher values than the females, in general (Tatlisumak et al., 2008; Michel et al., 2015). Uthman et al. demonstrated that by adding craniometric measurements to the frontal sinus patterns, greater precision is obtained in determining sex (Uthman et al., 2010). Nevertheless, Xavier et al. (Xavier et al., 2015) and Goyal et al. (Goyal et al., 2013) reported that the frontal sinus has limited application as only sex predictor, even though it is effective for identification. For this purpose, it should be used only when other parameters are not effective.

Maxillofacial imaging exams can be used as antemortem records for forensic analysis. Concerning frontal sinus images, frontal teleradiographies and CBCTs are of great value. As these exams can be part of orthodontical records, it is very important that orthodontists are aware of the forensic importance and application of these imaging exams, and keep them properly.

Identification methods are comparision methods; it is necessary to have a suspicion about the identity of the individual, and ask the family to provide his/her antemortem data. In this context, orthodontic imaging exams, if available, can be fundamental. They can even be the only identification possibility, before thinking on DNA analysis (which takes more time to be performed and is much more expensive than imaging comparison).

\section{Conclusion}

The frontal sinus radiographic analysis is a useful tool for human identification, as it usually provides a high degree of precision. Together with two-dimensional analysis of frontal sinuses, 3D images are of great value for human identification. Although three-dimensional analysis is not yet a routine, its use in Forensics is undoubtedly an excellent tool provided by new technologies. Therefore, it is important that orthodontists know this possibility, be aware of the importance of imaging exams in Forensics, and properly keep their patients' imaging records. 
In Forensics, digital methods use to be fast, efficient and objective. Additional research must be carried out in order to create standardized protocols using new technologies, especially $3 \mathrm{D}$ analysis of frontal sinuses. This would improve the work of Forensic experts, helping Justice and Society.

\section{Acknowledgments}

\section{Funding}

This study was financed in part by the Coordenação de Aperfeiçoamento de Pessoal de Nível Superior - Brasil (CAPES) Finance Code 001.

\section{References}

Andrade, A. M. C., Gomes, J. A., Oliveira, L. K. B. F., Santos, L. R. S., Silva, S. R. C., Moura, V. S., \& Romão, D. A. (2021). Odontologia legal - o papel do Odontolegista na identificação de cadáveres: uma revisão integrativa. Research, Society and Development, 10,2 , e29210212465.

Barros, F., Serra, M. C., Kuhnen, B., Scarso Filho, J., Gonçalves, M., \& Fernandes, C. M. S. (2021). Midsagittal and bilateral facial soft tissue thickness: a ConeBeam Computed Tomography assessment of Brazilian living adults. Forensic Imaging. 200444.

Besana, J. L., \& Rogers, T. L. (2010). Personal identification using the frontal sinus. J Forensic Sci., 55 (3), 584-9.

Buscatti, M. Y. (2009). Avaliação da presença de expansão basilar e de septos no seio esfenoidal humano por meio de tomografia computadorizada de feixe cônico. [Tese]. São Paulo: Universidade de São Paulo.

Camargo, J. R. (2000). Estimativa do sexo, através das características radiográficas dos seios frontais. [Dissertação]. Piracicaba: Universidade Estadual de Campinas.

Cappabianca, S., Perillo, L., Esposito, V., Iaselli, F., Tufano, G., Thanassoulas, T. G., Montemarano M, Grassi R., \& Rotondo A. (2013). A computed tomography-based comparative cephalometric analysis of the Italian craniofacial pattern through 2,700 years. Radiol Med., 118, 276-90.

Caputo, I. G. C., Prado, F. B., Daruge Júnior, E., \& Muglia, V. F. (2011). Seios Frontais na Identificação Humana: Revisão de Literatura. J Forensic Sci, Med Law and Bioethics, 1 (1), 8-14.

Carvalho, S. P. M., Silva, R. H. A., Lopes-Júnior, C., \& Peres, A. S. (2009). Use of images for human identification in forensic dentistry. Radiol Bras., 42 (2), $125-130$.

Conselho Federal de Odontologia. (2012). Código de ética odontológica. Resolução CFO n. 118, de 11 de maio de 2012 . Retrieved from https://website. cfo. org. br/wp-content/uploads/2018/03/codigo_etica. pdf.

Cossellu, G., Luca, S., Biagi, R., Farronato, G., Cingolani, M., Ferrante, L., \& Cameriere, R. (2015). Reliability of frontal sinus by cone beam - computed tomography (CBCT) for individual identification. Radiol Med., 120 (12), 1130-6.

Cox, M., Malcolm, M., \& Fairgrieve, S. I. (2009). A new digital method for the objective comparison of frontal sinuses for identification. J Forensic Sci., 54 (4), 761-72.

Dostalova, T., Eliasova, H., Seydlova, M., \& Broucek, J. V. (2012). The application of CamScan 2 in forensic dentistry. J Forensic Leg Med., 19(7), 373-80.

Emirzeoglu, M., Sahin, B., Bilgic, S., Celebi, M., \& Uzun, A. (2007). Volumetric evaluation of the paranasal sinuses in normal subjects using computer tomography images: a stereological study. Auris Nasus Larynx., 34, 191-5.

Fernandes, C. M. S., Pereira, F. D. A. S., Silva, J. V. L., \& Serra, M. C. (2013). Is characterizing the digital forensic facial reconstruction with hair necessary? A familiar assessors' analysis. Forensic Sci Intern., 229, 164. e1-164. e5.

Franco, R. P. A. V., Franco, A., Fernandes, M. P., Pinheiro, A. A., \& Silva, R. H. A. (2020) Radiographic assessment of the influence of metopism in frontal sinus morphology - a systematic review. Res Soc Dev, 9(10), e5719108993.

Gadekar, N. B., Kotrashetti, V. S., Hosmani, J., \& Nayak, R. (2019) Forensic application of frontal sinus measurement among the Indian population. J Oral Maxillofac Pathol., 23, 147-151.

Garib, D. G., Raymundo Júnior, R., Raymundo, M. V., Raymundo, D. V., \& Ferreira, S. B. (2007). Tomografia computadorizada de feixe cônico (Cone Beam): entende este novo método de diagnóstico por imagem como promissora aplicabilidade na Ortodontia. Rev Dent Press Ortodon Ortop Facial, $12,139-156$.

Gioster-Ramos, M. L., Silva, E. C. A., Nascimento, C. R., Fernandes, C. M. S., \& Serra, M. C. (2021) Técnicas de identificação humana em Odontologia Legal. Res Soc Dev, 10(3), e20310313200.

Goyal, M., Acharya, A. B., Sattur, A. P., \& Naikmasur, V. G. (2013). Are frontal sinuses useful indicators of sex? J Forensic Leg Med., 20 (2), 91-4.

Gruber, J., \& Kameyama, M. M. (2001). O papel da radiologia em Odontologia Legal. Pesqui Odontol Bras.,15, $263-268$. 
Hashim, N., Hemalatha, N., Thangaraj, K., Kareem, A., Ahmed, A., Hassan, N. F. N., \& Jayapralash, P. T. (2015). Practical relevance of prescribing supermposition for determining a frontal sinus pattern match. Forensic Sci Int., 253, 137.

Jun, B. C., Song, S. W., Kim, B. G., Kim, B. Y., Seo, J. H., Kang, J. M., Park, Y. J., \& Cho, J. H. (2010). A comparative analysis of intranasal volume and olfactory function using a three-dimensional reconstruction of paranasal sinus computed tomography, with a focus on the airway around the turbinates. Eur Arch Otorhinolaryngol., 267, 1389-95.

Kim, D. I., Lee, U. Y., Park, S. O., Kwak, D. S., \& Han, S. H. (2013). Identification Using Frontal Sinus by Three-Dimensional Reconstruction from Computed Tomography. J Forensic Sci., 58 (1), 5-12.

Kuhnen, B., Fernandes, C. M. S., Barros, F., Scarso Filho, J., Gonçalves, M., \& Serra, M. C. (2021). Facial soft tissue thickness of Brazilian living subadults. A Cone-Beam Computed Tomography study. Forensic Imaging. 200434.

Manganotti, A. B. M., Faria, N. C., Franzak, F. D. \& Amaral, M. A. (2021). Análise e classificação da rugosidade palatina em um grupo de jovens adultas brasileiras. Res Soc Dev, 10(1), e46810111743.

Michel, J., Paganelli, A., Varoquaux, A., Piercecchi-Marti, M. D., Adalian, P., Leonetti, G., \& Dessi, P. (2015). Determination of Sex: Interest of Frontal Sinus 3D Reconstructions. J Forensic Sci., 60 (2), 269-73.

Nikam, S. S., Gadgil, R. M., Bhoosreddy, A. R., Shah, K. R., \& Shirsekar, V. U. (2015). Personal identification in forensic science using uniqueness of radiographic image of frontal sinus. J Forensic Odontostomatol., 33(1), 1-7.

Oliveira, A. C. J., Conci, R. A., Sbardelotto, B. M., Garbin Júnior, E. A., \& Griza, G. L. (2020). Tratamento cirúrgico de fratura em parede anterior do seio frontal. Res Soc Dev, 9(9), e850998118.

Pereira, A. S., Shitsuka, Dorlivete Moreira Parreira, F. J., \& Shitsuka, R. (2018). Metodologia da Pesquisa Científica - Licenciatura em Computação. Retrieved from https://repositorio. ufsm. br/bitstream/handle/1/15824/Lic_Computacao_Metodologia-Pesquisa-Cientifica. pdf?sequence=1.

Pfaeffli, M., Vock, P., Dirnhofer, R., Braun, M., Bolliger, S. A., \& Thali, M. J. (2006). Post-mortem radiological CT identification based on classical antemortem X-ray examinations. Forensic Sci Int., 171 (2-3), 111-7.

Pondé, J. M., Andrade, R. N., Via, J. M., Metzger, P., \& Teles, A. C. (2008). Anatomical Variations of the Frontal Sinus. Int J Morphol., 26 (4), $803-8$.

Quatrehomme, G., Fronty, P., Sapanet, M., Grévin, G., Ollier, A., \& Bailet, P. (1996). Identification by frontal sinus pattern in forensic anthropology. Forensic Sci Int., 83, 47-153.

Ribeiro, F. A. (2000). Standardized measurements of radiographic films of the frontal sinuses: an aid to identifying unknown persons. Ear Nose Throat J., 79, $26-33$.

Riepert, T., Ulmcke, D., Scheweden, F., \& Nafe, B. (2001). Identification of unknown dead bodies by X-ray image comparison of the skull using the X-ray simulation program FoXSIS. Forensic Sci Int., 117, 89-98.

Rothwell, B. R. (2001). Principles of dental identification. Dent Clin North Am., 45 (2), 253-70.

Santos, K. C., Fernandes, C. M. S. \& Serra, M. C. (2011) Evaluation of a digital methodology for human identification using palatal rugoscopy. Braz J Oral Sci. 10(3): 199-203.

Serra, M. C., Herrera, L. M., \& Fernandes, C. M. S. (2012). Importância da correta confecção do prontuário odontológico para identificação humana. Relato de caso. Rev Asoc. Paul. Cir Dent., 66(2), 100-104.

Serra, M. C., Scarso Filho, J., Scolozzi, P., Sant’Ana, E., Vasconcellos, R. J. H., Genú, P. R., \& Fernandes, C. M. S. (2014) Prontuário clínico/cirúrgico tradicional e digital em odontologia: aspectos éticos, legais e bioéticos envolvidos. In: Pinto, T., Vasconcellos, R. J. H., \& Prado, R. (Org). Pro-Odonto Cirurgia (p. p. 41104) Porto Alegre: Artmed Panamericana.

Silva, R. F., Chaves, P., Paranhos, L. R., Lenza, M. A., \& Daruge Júnior, E. (2011). Utilização de documentação ortodôntica na identificação humana. Dental Press J Orthod., 16, 52-7.

Silva, R. F., Cruz, B. V. M., Júnior, E. D., Daruge, E., \& Francesquini, J. L. (2005). La importancia de la documentación odontológica en la identificación humana. Acta Odontol Venez., 43(2), 67-74.

Silva, R. F., Paranhos, L. R., Martins, E. C., Fernandes, M. M., \& Daruge Júnior, E. (2009). Associação de duas técnicas de análise radiográfica do seio frontal para identificação humana. Rev Sul-Bras Odontol., 6, 310-5.

Silva, R. F., Picoli, F. F., Rodrigues, L. G., Silva, M. A. G. S., Felisari, B. F., \& Franco, A. (2021). When a single central incisor makes the difference for human identification - a case report. Research, Society and Development, 10, 1, e24210111010.

Silva, R. F., Pinto, R. N., Ferreira, G. M., \& Júnior, E. D. (2008). Importância das radiografias de seio frontal para a identificação humana. Rev Bras Otorrinolaringo., 75, 798.

Silva, R. F., Prado, M. M., Barbieri, A., \& Daruge Júnior, E. (2009). Utilização de registros odontológicos para identificação humana. Rev Sul-Bras Odontol., 6, 95-9.

Silva, R. F., Rodrigues, L. G., Manica, S., Franco, R. P. A. V., \& Franco, A. (2019). Human identification established by the analysis of frontal sinus seen in anteroposterior skull radiographs using the mento-naso technique: a forensic case report. Rev. Bras. Odontol. Leg., 6 (1), $62-66$.

Singh, S., Bhargava, D., \& Deshpande, A. (2013). Dental orthopantomogram biometrics system for human identification. J Forensic Leg Med., 20 (5), $399-401$. 
Soares, C. B., Almeida, M. S., Lopes, P. M., Beltrão, R. V., Pontual, A. A., Ramos-Perez, F. M. M., Figueroa, J. N., \& Pontual, M. L. (2016). Human identification study by means of frontal sinus imaginological aspects. Forensic Sci Int. 262, 183-189.

Tatlisumak, E., Ovali, G. Y., Asirdizer, M., Aslan, A., Ozyurt, B., Bayindir, P., \& Tarhan, S. (2008). CT study on morphometry of frontal sinus. Clin Anat., 21 (4), 287-93.

Tatlisumak, E., Ovali, G. Y., Aslan, A., Asirdizer, M., Zeyfeoglu, Y., Tarhan, S. (2007). Identification of unknown bodies by using CT images of frontal sinus. Forensic Sci Int., 166, 42-48.

Trevelin, L. T., \& Lopez, T. T. (2012). A utilização de radiografias do seio frontal na identificação humana : uma revisão de literatura. RPG., 19 (3): 129-33.

Tucunduva, M. J. A. P. S., \& Freitas, C. F. (2008). Estudo imaginológico da anatomia da cavidade nasal e dos seios paranasais e suas variações por meio da tomografia computadorizada helicoidal. Rev. Pos-grad., 15, 46-52.

Uthman, A. T., Al-Rawi, N. H., Al-Naaimi, A. S., Tawfeeq, A. S., \& Suhail, E. H. (2010). Evaluation of frontal sinus and skull measurements using spiral CT scanning: An Aid in unknown person identification. Forensic Sci Int., 197, 124.

Wood, R. E. (2006). Forensic aspects of maxillofacial radiology. Forensic Sci Int., 159, 47-55.

Xavier, T. A., Terada, A. S. S. D., \& Silva, R. H. A. (2015). Forensic application of the frontal and maxillary sinuses: A literature review. J Forensic Radiol Imaging., 3 (2), 105-10. 